\title{
THE INFLUENCE OF USING THINK PAIR SHARE AND PAIRS CHECK TEHNIQUE TOWARD STUDENTS' WRITING ABILITY IN RECOUNT TEXT AT THE STUDENTS OF SMP N 2 PEKALONGAN ACADEMIC YEAR 2013/2014
}

\author{
Lia Aris Tantya \\ (English Teacher at Junior High School) \\ Syaifudin Latif Darmawan \\ (Dosen Universitas Muhammadiyah Metro) \\ syaifudinlatif@yahoo.co.id
}

\begin{abstract}
The objective of this research are to find out whether, the result of students' score by using Think Pair Share Technique maximal, the result of students' score by using Pairs Check Technique maximal and students' score of Writing Ability in Recount Text, how far the result of Influence of Using Think Pair Share and Pairs Check Tehnique toward Students Writing Ability in Recount Text. This research is Quantitative research. Research design that will be used in this research is true experimental design. The population of this research is the students' of SMP N 2 Pekalongan in 2013/2014 that consist of 603 students. The sample is 60 students. As the sample, 30 as experimental class and 30 as control class. In taking sample, the researcher used the cluster random sampling. The data collecting tehniques the researcher used are try-out, pre-test, treatment and post-test. The data analyzing tehniques, the researcher used normality test, homogenity test and hypothesis test. The differences of both the tehnique are TPS Tehnique can make students enjoy and fun in learning process because it is adopted by Share and can make students be active in learning. Based on the data analysis, the researcher uses $t_{- \text {test }}$ formula. The researcher got the

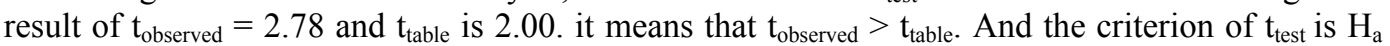
accepted if $t_{\text {observed }}>t_{\text {table }}$. So, there is differences between using TPS and Pairs Check tehnique toward students' writing ability in recount text at the students of SMP N 2 Pekalongan in academic year 2013/2014.
\end{abstract}

Key Words: $\quad$ TPS Tehnique, Pairs Check Tehnique, Writing Ability in Recount Text

There are four skills in English as

foreign language. They are

listening, speaking, reading and writing. Writing is one of four

basic skills. It is very important in

teaching and learning English. 
Writing involves some language components (spelling, grammar, vocabulary, and punctuation). Richard (2000, 10) states that writing is the most difficult skill for second language learners to be mastered. The difficulty lies not only in generating and organizing ideas, but also in translating these ideas.

Writing ability is an activity a person expresses them ideas, thought, expressions, and feelings which use for communicating to the readers in the form of written words. Fuethemore, Flynn and Stainthorp (2006, 23) states that Writing ability is a complex process that allows writers to explore thoughts and ideas, and make them visible and concrete. Many students' get difficulty and sometimes feel bored in writing subject. It is because sometimes the students' confuse and they do not know what they should be write. Besides, students' have difficulty to express their idea. Ideally, students' should master the writing skill to support the others skill, such; listening, speaking, and reading. The difficulty to express the idea becomes a problem that influences the development of their writing skill.

The tehnique of teaching can influence learning process of writing. Many teachers get difficult to find a good and suitable tehnique in learning of writing, so sometimes the purpose of learning can not be achieved. Using the suitable tehnique becomes one of the factors which influences students writing skill. Unsuitable tehnique of learning process becomes one of factors that make students confused in writing. 
make the errors of grammatical

Ditjen Dikti (1985, 5) state that

minimum mastering the material sometime are made basic graduated for the students who learn the material. But then usually up to mastery moving material between $75 \%$ to $80 \%$.

the researcher also found some factors which supporting the data above, those are internal factor and external factor. The first is internal factor, the internal factor is the students find difficulties in developing their idea in writing and make their writing unified. They have problem in building sentences with appropriate grammar and vocabulary. They are passive during the teaching learning process; they felt difficult to use of conjunction to connect the sentence and sentence before. The most of the students form syntactical.

Think pair share is one of the cooperative learning methods. There are positive effect in using this tehnique. Positive effect of cooperative learning have been consistently found on such diverse outcomes at self-esteem, intergroup relations, acceptance of academically handicapped students, attitudes toward school, and ability to work cooperativelly. Students have the opportunity to learn higher-level thinking skill from their peers, gain the extra time or prompting they may need, and gain selfconfidence.

In other words, Pairs Check is a way to structure pair work on mastery-oriented worksheets. Students work in teams of four with two sets of partners. Students to be patient and it train the 
students to give and receive

motivation from the partner appropriately and effectively. Besides, the students to be open to constructive criticism or suggestions from their partner.

Based on problem background above, some problems can be identify. They are:

1. The students' knowledge of using Think Pair Share is low.

2. The students' score of using Think Pair Share have not yet maximal.

3. The students' knowledge of using Pairs Check Technique is still low.

4. The students' score of using Pairs Check Technique have not yet maximal.

5. The students' knowledge of writing ability in recount text is still low.
6 . The students' score of writing ability in recount text have not yet maximal.

7. The Influence of Using Think Pair Share and Pairs Check Tehnique toward Students Writing Ability in Recount Text have not yet to do.

The objective of this research as follow :

1. To find out whether the result of students' score by using Think Pair Share Technique maximal?

2. To find out whether the result of students' score by using Pairs Check Technique maximal?

3. To find out whether the students' score of Writing Ability in Recount Text?

4. To find out how far the result of Influence of Using Think Pair Share and Pairs Check Tehnique toward Students Writing Ability in Recount Text? 


\section{Method}

While learning in classroom instruction and learning process conducted by educators and learners the school enviroment. Because learning is series of body to get something changes in behaviour as a resut of the experience of individuals with the enviroment related cognitive, affective and psychomotor.

The result of the research can used by students to increase their knowledge about english lesson especially ability in recount text.

Think Pair Share tehnique is one of tehnique that has three steps in learnig that are thinking individually, pairing with partner and sharing the information. The teacher give some minutes for students to think about the topic in their own idea. Each students should be paired with another students. Teacher may choose whether to assign pairs or let students pick their own partner. Then, the students share their thinking with their partner, discuss idea and ask question of their partner about their thought on the topic. This tehnique will create good work within the group. Each member will get some knowledge from their partner which they do not know before.

Pairs Check is a way to structure pair work on mastery-oriented worksheets. Students work in teams of four with two sets of partners. This is give the opportunity for students to offer help or guidance to others in a good way, Train students to ask questions or ask for help to others ( partner), but in the fact that each partner is not a pair of students with a better learning abilities. So sometimes coaching function is 
not going well. The students

divide the problems in half and

take turns working the problems.

The checking occurs as each one

describes how to work the

problem or handle the situation.

\section{Subject}

The researcher can conclude that the subject of this research is all of students in SMP N 2 Pekalongan. There are eightteen classes are VII.1, VII.2, VII.3, VII.4, VII.5, VII.6, VIII.1, VIII.2, VIII.3， VIII.4， VIII.5， VIII.6, IX.1, IX.2, IX.3, IX.4, IX.5, XI.6. The total number of population are 603 students. But the researcher has determined two classes randomly.

\section{Sample}

Sugiyono (2010:81) states that Sample is part of whole and characteristic from population itself. In this research the researcher will take two classes from all of the population at SMP N 2 Pekalongan academic year $2013 / 2014$ as the sample. They are experimental class and control class. All population of classes is 603 students, and the researcher will take it by using stratified random sampling because the members of sample are homogeneous.

The researcher will use the tests and the tests consists of pre-test and post test. The tests to measure the result of students' writing ability in recount text before and after the treatment. The researcher will use essay test to measure the result of students' writing ability in recount text before and after the treatment. The researcher administers try out to know whether the question of writing ability test valid and reliable or not. After knowing the 
reliability, the researcher delivered the writing recount text before and after the treatment.

The pre-test is given in order to know how far the students' ability in recount text before being given the treatment. It determined the readiness instructional program and to diagnosed individual's specific strengths and weakness in recount text. Pre test consist of 1 question with 2 text must be choosen for the students.

The post-test is given after the treatment. It will be done in order to know the students' development in writing recount text after having the treatment. The topic test have the same level of difficulty as in the pre-test.

In evaluating the students' writing score, the researcher use scoring rubric, Jacobs et al (1990: 90) proposed five aspect of writing to evaluate the students' ability in writing recount text;

1. Content refers to substance of recount text,

2. Organization refers to the logical organization of the recount text content,

3. Vocabulary refers to the selection of words there are suitable with the content,

4. Language use refers to the use of the correct grammatical and syntactic patern,

5. Mechanic refers to the use graphic conventionalof the language.

\section{Result}

The data which described in this research are the data of the influence using Think Pair Share and Pairs Check as cooperative 
learning tehnique in writing

ability between the experimental class and control class.

After given the treatments until last meeting. They relized that tehniques can helm them to write easier and enjoyable.

In experimental class, for the first treatment, the highest score was 74 and the lowest score was 56. In the second treatments, the highest score was 74 and the lowest score was 58 . In the third treatment, the highest score was 76 and the lowest score was 62 and the fourth treatment, the highest score was 80 and the lowest score was 66.

In the other hand, in control class for the first treatment, the highest score was 72 and the lowest score was 50. In the second treatments, the highest score was 76 and the lowest score was 50 . In the third treatment, the highest score was 76 and the lowest score was 60 and the fourth treatment, the highest score was 78 and the lowest score was 60 .

The researcher administered the post-test of experimental class and control class on the same day at different times. In experimental class the highest score was 95 and the lowest score was 60 which had a mean 73,7 and standard deviation 8,74. Meanwhile, in control class the highest score was 89 and the lowest score was 54 which had a mean 67,7 and standard deviation 8,94 .

Based on the finding, the result of normality of post-test, it is obtained that $\mathrm{x}^{2}$ hit is lower than $\mathrm{x}^{2}{ }_{\text {daf }}$ in both of significant level $5 \%(\alpha=0.05)$ and $1 \%(\alpha=0.01)$. So the hypothesis $\mathrm{H}_{\mathrm{a}}$ is accepted. It means that both samples in this research have normal distribution. 
And the hypothesis it was shown that t-ratio is higher than t-table.

On significant level 0.05 was 2.00. Based on the criteria above, Ho was rejected and $\mathrm{Ha}$ was accepted. It means that, there was difference result of using Think Pair Share and Pairs Check Tehnique toward students' writing ability in recount text and Think Pair Share tehnique was more effective of students' writing ability in recount text at the students' of SMP N 2 Pekalongan in Academic Year 2013/2014.

\section{Discussion}

To clarify the purpose of this study, the researcher used a test to write recount text (which used in the pre-test and post-test) as a research instrument, the average score of pre-test and post-test for each class using Think Pair Share and Pairs Check tehnique compared to find out the advantages of both score. Calculation result provides evidence that the post-test students in experimental class were better than control class. This can be seen when the posttest scores of the students compare with pre-test scores. The result showed that there were significant difference between pre-test and post-test (post-test $>$ pre-test). Data analyzed by using $t$-test on TPS tehnique. The findings show that signficant value is lower than 0.05 , $(0.008<0.05, \mathrm{r}=0.369)$, meaning that TPS improves the students' ability in writing recount text. The students claim that this tehnique offers interesting learning, challenge creativity and serves new simple tehnique to write especially in recount text. As Lyman (1985, 83) states that 
Think Pair Share is cooperative learning tehnique, involving individual pairs and group of students. Think Pair Share tehnique was the both a lesson plan and pre-writing tehnique that cen help the students brainstrom before writing recount. It can also be used to introduce new vocabulary or review vocabulary. So, it is recommended for further researcher to conduct a research for other skill and others tehnique. It indicates by the score after the treatments (post-test score) of experimental group is higher than control group.

From the pervious calculation, the hypothesis can be accepted because $t_{\text {observed }}$ was 2.78 and $t_{\text {table }}$ was 2.00 on the criteria 1 and also $t_{\text {table }}$ was 2.66 on the criteria 2. It shows that the hypothesis of $\mathrm{H}_{\mathrm{a}}$ was accepted and $\mathrm{H}_{\mathrm{o}}$ was rejected. It means that there was significant difference between Think Pair Share and Pairs Check tehnique in writing ability in recount text for the students' of SMP N 2 Pekalongan and it also conclude that Think Pair Share tehnique was more effective than Pairs Check tehnique toward students' writing ability in recount text at the eight grade students' of SMP N 2 Pekalongan Academic Year 2013/2014.

The result were consistence with the result of research Hasanah (2007), entitled Improving Students' Writing Ability in Writing Reount Text through WH-Question at Class VIII.1 SMP N 1 Sukadana East Lampung. The aimed of the research was to improve the students' ability in writing recount text at class VIII.1 of Smp N 1 Sukadana, East 
Lampung in the first semester in 2007/2008. The result of the reseach showed that the implementation of WH-Question could improve the students' ability in writing recount text at class VIII.1 SMP N 1 Sukadana East Lampung. There were 14 of 42 students $(33,3 \%)$ got 60 or more in writitng recount text through WH-Questions at Cycle 1. While ,at Cycle II, there were 35 of 42 students' $(83,3 \%)$ got 60 or more. So it fulfil the criterion of success, it was $75 \%$ of students (32\%) got 60 or more.

In conclusion, The result Think Pair Share tehnique was more effective in students' writing ability in recount text than Pairs Check tehnique. It is proven by the result of pre-test and post-test.

CONCLUSION
Based on the objective and result of data analysis, the researcher draws his research conclusion as follows:

The result of writing ability in recount text using Think Pair Share and Pairs Check techniques at the eight grade students is high. The statement is supported by result of finding that $t_{\text {observed }}=2,78$ is higher than $t_{\text {table }}=2,66$ on the criterion 0,01. In addition, the hypothesis $\mathrm{H}_{\mathrm{a}}$ in this research is accepted. It means that The result of writing ability in recount text by using Think Pair Share and Pairs Check techniques at the students of SMP N 2 Pekalongan has different result in students' writing ability in recount text.

There are different results of using Think Pair Share and Pairs Check techniques toward students' writing ability in 
recount text at the eight grade students is high. The differences showed that based on the result of $t_{\text {test, }}$ where $t_{\text {observed }}$ is 2,78 are higher than $t_{\text {table }}$ is 2,00 on the criterion 0,05 . It means that students' writing ability in recount text will be higher if the teacher uses Think Pair Share and Pairs Check techniques in learning process. So, the researcher concluded that there are different results of using Think Pair Share and Pairs Check techniques towards students' writing ability in recount text at the students' of SMP $\mathrm{N} 2$ Pekalongan in academic year of 2013/2014.

Think Pair Share technique is more effective than Pairs Check technique of students' writing ability in recount text at the students' of SMP N 2 Pekalongan in academic year of $2013 / 2014$. It can be seen from the result of $t_{\text {test }}$, where $t_{\text {observed }}$ was 2,78 were higher than $t_{\text {table }}$ was 2,00 on criterion 0,05 and the average score of the students who were taught by using Think Pair Share technique was higher than Pairs Check technique. So, it is clearly that the hypothesis $\mathrm{Ha}$ in this research was accepted. The improvement of the students' writing ability in recount text by using Think Pair Share technique is higher than using Pairs Check technique. Beside, the students enjoy and feel fun in accepting information especially in recount text. Therefore, the teacher is easier in transfering material to the sudents.

The result of influence Think Pair Share and Pairs Check Technique towards students' writing ability in recount text are significant. It can be seen from the result of $t_{\text {test}}$, 
where $t_{\text {observed }}$ was 2,78 were

higher than $t_{\text {table }}$ was 2,00 on

criterion 0,05 and the average score of the students who were taught by using Think Pair Share technique was higher than Pairs Check technique. So, it is clearly that the hypothesis $\mathrm{Ha}$ in this research was accepted. The improvement of students' writing ability in recount text by using Think Pair Share technique is higher than using Pairs Check technique at the students' of SMP N 2 Pekalongan academic year 2013/2014.

Based on the result and discussion, the researcher concluded that there is any different result of Student's writing ability in recount text by using using Think Pair Share and Pairs Check techniques, and Think Pair Share Technique is more effective in writing ability learning process than Pairs Check Technique in learning process for the students at the students' of SMP N 2 Pekalongan academic year 2013/2014.

\section{SUGGESTION}

Based on the description above, the researcher proposes some suggestions that to improve the students' writing ability in recount text, the english teacher can use Think Pair Share tehnique. Think Pair Share tehnique can make the students feel enjoy in learning process and it will motivate the students and they can be more active and innovative when they follow the teacher's instruction.

For teaching writing, Think Pair Share tehnique is very good because it contains many ideas that the students their ideas iin writing actually in recount text. 
And also, Think Pair Share

tehnique is used to generate,

visualize, structure and classify ideas. As an aid to studying and organizing information, solving problem, making decisions in writing. It is advisable for teachers to use Think Pair Share tehnique because it is very easy to apply and also can improve students writing ability especially in recount text. For the students, Think Pair Share tehnique is cooperative learning that can they use to share their ideas in writing especially recount text. Both of them will feel enjoy during teaching learning process.

\section{REFERENCES}

Ahmad,Jazim (2010). Statistik. FKIP-UMMetro: UM Metro press.

Badger, Richard \& White, Goodith.(2000).A Process genre approach to Teaching Writing. ELT Journal54/2: 153-160
Brown, Douglas H (2001).Teaching by principles an interactive approach to language pedagogy, Second Edition : San Fransisco State University.

Derewianka,B (1992). Exploring how texts work. Australia: Primary English

Teaching Association.

Diharyono (1991). Teaching writing through story to improve students' writing ability. Lampung University: S1 Research Report.

Eggen, $\mathrm{P}$ and Khauchak, D (2012).Strategi dan model pembelajaran edisi keenam. Jakarta Barat:Permata Puri Media

Fadholi (2009). Optimalisasi media pembelajaran. Jakarta; Grasindo.

Fadholi, Arif.(2009). Kelebihan \&kekurangan TPS. Artikel (tidak diterbitkan).Diakses di http://arif fadholi.wordpress.com/20 09/12/2kelebihan-\& kekurangan-tps/ tgl 16September 2010.

Finocchiaro, $\mathrm{M}$ and Bonomo (1973). The foreign language teacher: $A$ guided for teacher. New York: Regent Publishing Company Inc. 
Flynn, N. And Stainthrop, R. (2006). The learning and theaching of reading and writing.

WileyBlackwell:Chicheste r.

Gay I.R.(2006). Educational research:competencies for analysis and applications.London: The Lehigh Press.

Hasanah.(2007). Improving students'writing ability in recount text through $\mathrm{WH}$ Question at class VIII.1 SMP N 1 Sukadana East Lampung. UM Metro: S1 Research Report.

Kagan, S. (1994). The structural approach to cooperative learning. Educational Leadership, 47(4): 1215.

Kagan, S. (2003) "Cooperativelearning structures for brain-compatible instruction." In J. Cooper et. al. (Eds), Small Group Instruction in Higher Education. Stillwater, OK:New Forums Press, pp. 303-304

Karwono. Dwiyogo W.D (1992). Jurnal metode eksperimen dalam penelitian. Malang: IKIP Malang.

Lie, Anita. (2008). Cooperative Learning.Mempraktikkan

Hook,E(2002). Targeting text:recount,procedure, exposition, up level.Singapore: Blake Education.

Hornby, G.(2000). Improving parental invlovement. London : Cassell

Jacobs, Holly S (1990). Testing ESL composition: A Practical approach. Massachusetts:Newbury House Publisher, Inc.

Junaidi .(2008). Menulis sebagai suatuketerampilan berbahasa. Bandung: Angkasa.

Cooperative Learning di Ruang

Kelas. Jakarta:Grasindo.

Lyman, F and Davidson, N (1985).Teaching cooperative learning : the challenge for teacher education. Albany: University of New York press.

Mclaren.(2006). Mastering writing esential. New jersey : Prentice Hall Regent.

Miranti, R.A (2008). The use of picture series in teaching reading recount text to the first year students of SMA AL-HUDA Jati Agung. 
Lampung University:

Unpublished Script.

Napoleon. (1769-1821). The concept of ability. Encarta Dictionaries.

Nastiti, E.E.(2013). The influence students' writing ability through discussion method at the tenth grade of smk muhammadiyah 1 Rumbia. UM Metro : Unpublished Script.

Siahaan,S (2008). Issues in linguistics.Yogyakarta:

GrahaIlmu.

Slavin, Robert E (1991). Synthesis of Research on Cooperative Learning. London

Sugiyono(2013). Metode penelitian pendidikan pendekatan kuantitatif, kualitatif dan $R \quad \&$ D.Bandung : Alfabeta

Tim Dosen Universitas Muhammadiyah Metro (2013). Guidance for Proposal Seminar S1 Thesis Edition Revision. Metro : UMM Press.

Whitehead, Alfred North (18611947). The concept of nature: Tarner lectures delivered in Trinity College, November: The University press 